\title{
Genetic Divergence Among Gerbera spp. Genotypes Based on Morphological Traits
}

\author{
Daiane de Pinho Benemann ${ }^{1}$, Luis Willian Pacheco Arge $^{2}$, Willian Silva Barros ${ }^{3}$, Valmor João Bianchi ${ }^{1}$, Monique \\ Inês Segeren ${ }^{4} \&$ José Antonio Peters ${ }^{1}$ \\ ${ }^{1}$ Laboratory of Plant Tissue Culture, Institute of Biology, Department of Botany, Federal University of Pelotas \\ (UFPEL), Pelotas, RS, Brazil \\ ${ }^{2}$ Plant Genomics and Breeding Center, FAEM, Federal University of Pelotas, Pelotas, RS, Brazil \\ ${ }^{3}$ Institute of Physics and Mathematics, Department of Mathematics and Statistics, Federal University of Pelotas \\ (UFPEL), Pelotas, RS, Brazil \\ ${ }^{4}$ PróClone LTDA company, Holambra, SP, Brazil \\ Correspondence: Daiane de Pinho Benemann, Laboratory of Plant Tissue Culture, Institute of Biology, \\ Department of Botany, Federal University of Pelotas (UFPEL), Pelotas, RS, Brazil. Te: 55-53-8117-9975. E-mail: \\ Daiane_bio@yahoo.com.br
}

Received: January 4, 2013 Accepted: February 22, 2013 Online Published: April 15, 2013

doi:10.5539/jas.v5n5p35 URL: http://dx.doi.org/10.5539/jas.v5n5p35

\begin{abstract}
Gerbera is one of the most important ornamental flowers marketed worldwide. Information on the genetic variability of this species represents an important resource for improvement programs that rely on the selection of promising genotypes. The aim of the present study was to assess and characterize the genetic divergence among 32 gerbera accessions based on morphological traits by means of multivariate analysis. A total of 21 traits, nine quantitative and 12 qualitative, were analyzed using clustering analysis and the principal component method. Although the quantitative and qualitative traits were analyzed separately, joint analysis allowed for a more reliable interpretation of the genetic variability and also permitted the identification of wide dissimilarity among the investigated accessions. With regard to the quantitative traits, four main groups were observed, which was in partial agreement with the result of the analysis of canonical variables. The qualitative trait analysis, on the other hand, resulted in the formation of five groups. The traits that contributed most significantly to variability in gerbera were total width of the trans florets set and number of flowers. The data obtained in the present study may be applied directly to improve the design of controlled crosses between gerbera accessions and to better explore the hybrid effect in the process of genetic improvement in this species.
\end{abstract}

Keywords: dissimilarity, Gerbera spp., morphological descriptors

\section{Introduction}

Gerbera (Gerbera spp.), which belongs to the Asteraceae family and originates from Southern Africa and Asia, is an herbaceous, vivacious plant that grows to a height of approximately $45 \mathrm{~cm}$. The elongated leaves are arranged in rosettes, reaching up to $40 \mathrm{~cm}$ in length. Although juvenile leaves are round, adult leaves are characterized by slight incisions or divisions in the leaf margins. Furthermore, leaf blades exhibit variations in size and color depending on the cultivar. The flower buds originate in the axils of some leaves, develop large scapes, and exhibit a terminal inflorescence known as a capitulum. The floral stem is slightly hairy, and its length and diameter vary depending on the cultivar, plant age, and growth conditions. Some long-stem cultivars grow to approximately $60 \mathrm{~cm}$ in height and are appropriate for use as cut flowers, whereas the most compact cultivars are used as pot flowers (Infoagro, 2005).

Gerbera propagation can be sexual (through seeds) or asexual (vegetative); the latter is accomplished using stolons originating from adult plants and micro-propagation. Vegetative propagation is critical for the maintenance of characteristics of plants of interest, especially in the case of hybrids (Souza et al., 2005).

The Brazilian and international markets for ornamental plants continue to expand. In the first five months of 2011, the value of Brazilian exports and imports of ornamental plants reached \$7.60 million (USD) and \$15 million (USD), respectively. The main products exported by Brazil were seedlings of ornamental plants 
(69.01\%), followed by bulbs, tubercles, rhizomes, and other dormant components (12.14\%) (Junqueira \& Peetz, 2011).

The ornamental plant market is extremely dynamic and demands constant novelties. To meet such needs, advances in genetic improvement programs aligned with the consumers' demands are crucial (Filliettaz \& Andréa, 2007). The aim of the genetic improvement of ornamentals is to develop plants exhibiting novel and commercially valuable characteristics and plants that are more competitive with respect to cultivars already available in the market. In other words, the new cultivars must exhibit some advantage relative to those that are already available.

The success of improvement programs hinges on the genetic variability of the species and the process of selection applied to the species. For genetic diversity to be used and ultimately monetized, the accessions must be characterized, documented, and identified for their morpho-phenological, molecular, and agronomic traits. This information allows breeders to identify potentially promising genotypes for use in improvement programs (Borém \& Miranda, 2005).

In this regard, multivariate analysis techniques represent an alternative tool for clustering and/or describing a group of individuals because they assess the full set of descriptors simultaneously. Furthermore, these strategies consider sets of genotypes in the context of a complex of variables of interest for breeders, allowing for the selection of genotypes based on several aspects, particularly agronomic ones (Castineiras, 1990). Techniques such as regression (Beale et al., 1967), discriminant analysis (Mardia et al., 1979), principal component, and canonical analysis (Cruz et al., 2004) have been used for the selection or removal of variables aimed at the genetic improvement of plant species (Albuquerque, 2011).

Because morphological characterization is one of the first steps in the identification of accessions, the present study sought to characterize the genetic variability of gerbera accessions by estimating their genetic divergence and by clustering the accessions through multivariate analysis of quantitative and qualitative morphological traits.

\section{Materials and Methods}

\subsection{Plant Material and Morphological Evaluation}

In the present study, 32 accessions of gerbera were used (Table 1) from the germplasm bank of the Pró-Clone company, which is based in São Paulo, Brazil.

The experimental design was entirely randomized, with 32 treatments (accessions) and two repetitions of each accession. Assessment began when the plants reached the commercial stage, which corresponds to the time of blossoming, i.e., when two rows of disk flowers are open. Analysis of the nine quantitative traits was performed first, with the findings expressed as means, maximum and minimum values, standard deviation, and coefficient of variation.

The accessions were assessed by means of morphological characterization, including nine quantitative and 12 qualitative traits. The measurement of the quantitative traits was performed according to the official gerbera descriptors provided by the Ministry of Agriculture, Livestock and Food Supply (Ministério de Agricultura, Pecuária e Abastecimento-MAPA) (2005): 1- length of leaves, 2- width of the trans florets set, 3- length of outer ray florets, 4- width of outer ray florets, 5- number of leaves, 6- stem length, 7- stem diameter, 8-capitulum diameter, and 9- number of capitula per assessed accession.

The qualitative traits were assigned sequential numerical codes according to the official gerbera descriptors (MAPA, 2005) and modified as follows: 1. depth of the incisions at the central third of leaves: shallow (3), medium (5), deep (7); 2. hairs on the upper surface of leaves: present (1) and absent (2); 3. intensity of the green hue on the upper surface of leaves: light (1) and dark (2); 4. level of the apex of the outer ray florets relative to the apex of the involucre: below (1), same level (2), and above (3); 5. shape of the outer ray florets: narrow-elliptic (1) and narrow-obovate (2); 6. shape of the apex of the outer ray florets: sharp (1) and round (2); 7. number of colors of the outer ray florets: one (1) and two (2); 8. dark disk: absent (1) and present (2); 9. main color of stigma: white (1), yellow (2), orange (3), pink (4), red (5), purple (6), and brown (7); 10. main color of anthers: yellow(1), orange (2), pink (3), red (4), purple (5), and brown (6); 11. color of flowers: yellow (1), white (2), red (3), orange (4), and pink (5); 12. type of capitulum: simple (1), semi-double (2), and double (3). 
Table 1. Inflorescence type and capitulum color of 32 gerbera genotypes used in the morphological analysis

\begin{tabular}{|c|c|c|c|}
\hline Genotype name & Plant code* & Inflorescence type & Color \\
\hline Igor & $\mathrm{C} 1$ & Semi-double & Pink \\
\hline Terra Fame & $\mathrm{C} 2$ & Simple & Yellow \\
\hline Golden G. & $\mathrm{C} 4$ & Semi-double & Yellow \\
\hline Igor & $\mathrm{C} 5$ & Semi-double & Pink \\
\hline Kozak & C6 & Semi-double & Dark orange \\
\hline Selvagem & C7 & Simple & Red \\
\hline Pink Elegance & $\mathrm{C} 8$ & Double & Pink \\
\hline Golden G. & C9 & Semi-double & Yellow \\
\hline Golden G. & $\mathrm{C} 10$ & Semi-double & Yellow \\
\hline Deranagem & $\mathrm{C} 12$ & Semi-double & Pink \\
\hline Terra Fame & $\mathrm{C} 13$ & Simple & Yellow \\
\hline Golden G. & $\mathrm{C} 14$ & Semi-double & Yellow \\
\hline Deranagem & $\mathrm{C} 15$ & Semi-double & Pink \\
\hline Cariba & $\mathrm{C} 16$ & Semi-double & Red \\
\hline Igor & $\mathrm{C} 17$ & Semi-double & Pink \\
\hline Terra fame & $\mathrm{C} 18$ & Simple & Yellow \\
\hline Mystique & C19 & Simple & Orange \\
\hline Golden G. & $\mathrm{C} 20$ & Semi-double & Yellow \\
\hline Selvagem & $\mathrm{C} 21$ & Simple & Orange \\
\hline Cariba & $\mathrm{C} 22$ & Semi-double & Red \\
\hline Terra Fame & $\mathrm{C} 23$ & Simple & Yellow \\
\hline Golden G. & $\mathrm{C} 24$ & Semi-double & Yellow \\
\hline Terra Fame & $\mathrm{C} 25$ & Simple & Yellow \\
\hline Golden G. & $\mathrm{C} 26$ & Semi-double & Yellow \\
\hline Terra Fame & $\mathrm{C} 27$ & Simple & Yellow \\
\hline Terra Fame & $\mathrm{C} 29$ & Simple & Yellow \\
\hline Terra Fame & $\mathrm{C} 31$ & Simple & Yellow \\
\hline G32 & $\mathrm{C} 32$ & Simple & Yellow \\
\hline Monique & $\mathrm{C} 34$ & Semi-double & Red \\
\hline Orça & $\mathrm{C} 40$ & Simple & White \\
\hline Orça & $\mathrm{C} 42$ & Simple & White \\
\hline Pacific & $\mathrm{C} 45$ & Simple & White \\
\hline
\end{tabular}

*Identical genotypes are clones of a given cultivar and represent individuals from a single lineage that originated from the vegetative reproduction of the reference genotype.

\subsection{Statistical Analysis}

Analysis of the quantitative and qualitative traits was performed separately. The first requirement of a desired trait is the ability to differentiate cultivars for this trait. For this purpose, the quantitative traits were subjected to descriptive analysis. Multivariate analysis was subsequently performed using the Mahalanobis distance (D2) (Hair, 2005). Clustering was performed using the Unweighted Pair-Group Method Using an Arithmetic Average (UPGMA) (Sneath \& Sokal, 1973) to assess the potential of traits for genotypic discrimination when considered 
as a whole. Canonical analysis was also used for clustering, and the relative importance of the traits was estimated by Singh's (1981) method.

For clustering based on the qualitative traits, the recorded values were transformed into binary data, and the simple matching coefficient was applied to analyze the dataset. The dissimilarity matrix was calculated for subsequent classification using the hierarchical method, and a dendrogram was created using the UPGMA algorithm, as recommended by Rohlf (1970).

The cophenetic correlation coefficient (CCC) was calculated to test the efficiency of each clustering method, with a lower CCC value indicating a greater efficiency. All analyses were performed using Genes version 7.0 software (Cruz, 2006).

\section{Results and Discussion}

\subsection{Morphological Variability for Quantitative Traits}

To verify the morphological diversity based on quantitative descriptors, the mean, maximum and minimum values, standard deviation, and coefficient of variation of nine morphological traits in 32 gerbera accessions were analyzed. The data were collected over the same trial period from plants grown under the same environmental conditions. Given the observable morphological variability among the accessions, one can therefore infer that the accessions represent different genotypes.

The largest coefficient of variation was found for the number of capitula (49\%) and number of leaves (47\%); the lowest was found for capitulum diameter (12\%) (Table 2).

Table 2. Descriptive analysis of nine quantitative gerbera descriptors

\begin{tabular}{cccccc}
\hline Traits & Mean & Max & Min & SD & cv (\%) \\
\hline Length of leaves (cm) & 17.64 & 27.00 & 9.00 & 3.48 & 20.00 \\
Width of the trans florets set (cm) & 30.11 & 54.39 & 14.70 & 8.41 & 28.00 \\
Length of outer ray florets (mm) & 42.13 & 69.27 & 31.40 & 6.45 & 15.00 \\
Width of outer ray florets (mm) & 8.98 & 12.16 & 3.27 & 1.90 & 21.00 \\
Number of leaves & 19.48 & 61.00 & 6.00 & 9.09 & 47.00 \\
Stem length (cm) & 34.90 & 57.00 & 11.27 & 8.49 & 24.00 \\
Stem diameter (mm) & 5.61 & 10.90 & 2.27 & 1.19 & 21.00 \\
Capitulum diameter (cm) & 9.60 & 13.16 & 7.00 & 1.15 & 12.00 \\
Number of capitula & 1.77 & 5.00 & 1.00 & 0.86 & 49.00 \\
\hline
\end{tabular}

Max, Maximum; Min, Minimum; SD, Standard deviation; cv, Coefficient of variation.

According to Rocha et al. (2006), the coefficient of genetic variation indicates the presence of variability among evaluated accessions, with higher values corresponding to greater heritability and, consequently, the odds of finding superior individuals that will afford genetic gains during the process of selection. Further evidence supporting this assertion was provided by Ram et al. (2005), who found a high coefficient of genotypic variation and high levels of heritability for plant height, stalk diameter, and number of capsules per plant in the species Silybum marianum $\mathrm{G}$.

\subsection{Clustering of Quantitative Traits}

For the quantitative traits, the average Mahalanobis distance among accessions (D2 = 103) was used as a criterion for clustering (Figure 1). 


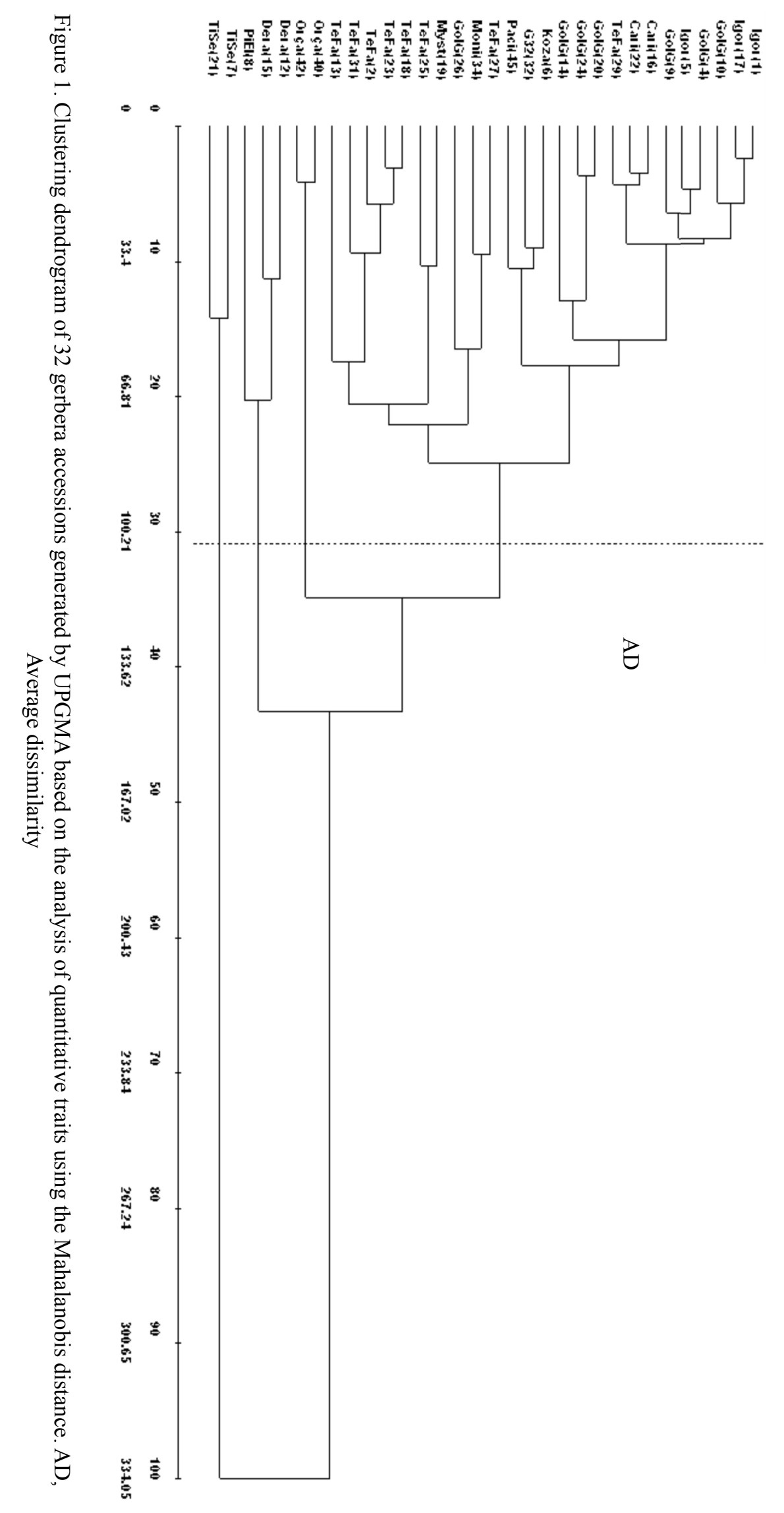


Four main groups were created in the dendrogram, with the first including most of the accessions: Igor $(1,5$, and 17); Golden G. (4, 9, 10, 14, 20, 24, and 26); Cariba (16 and 22); Terra Fame (2, 13, 18, 13, 25, 27, and 29); G32 (32); Pacific (45); Monique (34); Kozak (6); and Mystique (19). The second group included the Orça accessions (40 and 42); the third group included the Deranagem (12 and 15) and Pink Elegance (8) accessions; and the fourth group included the wild type accessions (7 and 21). In spite of some genetic distance, the similar accessions are clones of a given cultivar and represent individuals of a single lineage that originated by vegetative propagation. The fact that they are not identical may be indicative of mutation events over the course of several vegetative propagations.

The quantitative morphological traits that exhibited greater relative contribution were total width of the trans florets set, number of leaves, stem diameter, length of leaves, width of outer ray florets, stem length, number of capitula, and diameter of capitula (Figure 2). The first four traits explained $69.22 \%$ of the variability.

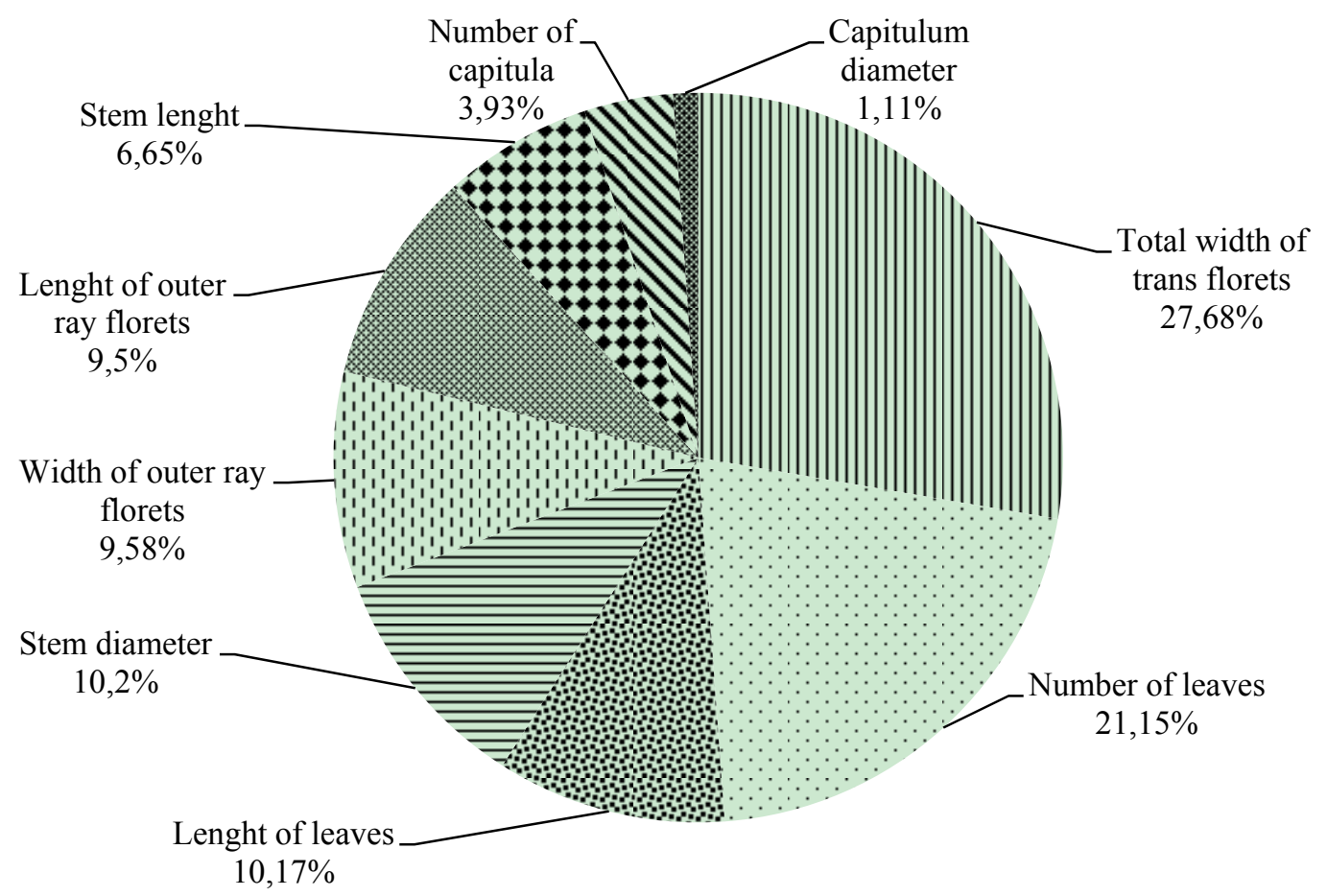

Figure 2. Relative contribution (\%) of the quantitative traits assessed in gerbera

In a study on gerbera, Cardoso et al. (2007) also found that the total width of the trans florets set was one of the most relevant traits explaining variability.

The largest divergence was found between accessions wild type (clone 21) and Pink Elegance (clone 8), with an average distance of 6.58. The most similar were accessions 23 and 18, both corresponding to Terra Fame, with a distance of 1.04. Cardoso et al. (2007) also found wide genetic diversity between Pink Elegance and Tipo Selvagem in a study on the genetic divergence of 13 gerbera genotypes.

For the average width of the trans florets set, the largest divergence was found between accession $8(53.17 \mathrm{~mm})$ and accession $21(15.07 \mathrm{~mm})$. For the average number of leaves, Pink Elegance (8) exhibited eight leaves, and wild type exhibited 46 leaves. For leaf length, Pink Elegance and wild type exhibited averages of $15.75 \mathrm{~cm}$ and $11 \mathrm{~cm}$, respectively.

The stem diameter trait varied from $3.04 \mathrm{~mm}$ to $5.55 \mathrm{~mm}$ for wild type and Pink Elegance, respectively. According to Hermans et al. (2006), stem diameter increases rigidity and plays an important role in preventing flowers from falling over under the following conditions: windy conditions in the cultivation field, transportation from the field to the treatment and selection site, packaging, and post-harvest processing. For cut flowers in general, carbon reserves in the stems also increase the potential longevity of flowers. Thus, stem length and diameter greater, the longer is the post-harvest durability. 
Cophenetic correlation analysis $(\mathrm{r}=0.84)$ was used to determine the consistency between the clustering analysis and the dissimilarity matrix. Although the stem length trait did not contribute significantly to variability, it nevertheless represents an important trait in the selection of genotypes to be used as cut flowers.

\subsection{Canonical Variables of Quantitative Traits}

In addition to the clustering data, complementary analysis based on canonical variables $(\mathrm{CV})$ was performed. Traits exhibiting higher percentages of variance were used to verify the dispersion of the genotypes on Cartesian coordinates to simplify the visualization and interpretation of the results, as recommended by Cruz and Carneiro (2006).

Analysis of the canonical variables showed that approximately $74.46 \%$ explained the total variance. $\mathrm{VC} 1, \mathrm{VC} 2$, and VC3 explained $44.93 \%, 18.83 \%$, and $10.70 \%$, respectively, and thus fit a three-dimensional graphical representation (Figure 3). Observation of the distribution of genotypes in each group revealed partial agreement between the UPGMA clustering analysis and the canonical variables, as four groups were formed and some accessions clustered together regardless of the algorithm employed.

Accessions 7 and 21 (wild type) clustered closely to one another (Figure 3) and distantly from the remainder of the accessions, corroborating the dendrogram results (Figure 1). A similar result was found for accession 8 (Pink Elegance) and accessions 12 and 15 (both Deranagem), which also clustered closely to one another using both clustering methods. Again consistent with the dendrogram results, accessions 40 and 42 (both Orça) clustered closely to one another. However, accessions 13 (Terra fame) and 6 (Kozak), which were mutually distant in the dendrogram, were close to one another in the canonical analysis. The remainder of accessions belonging to group 1 in the dendrogram also clustered into one single group in the canonical variable analysis.

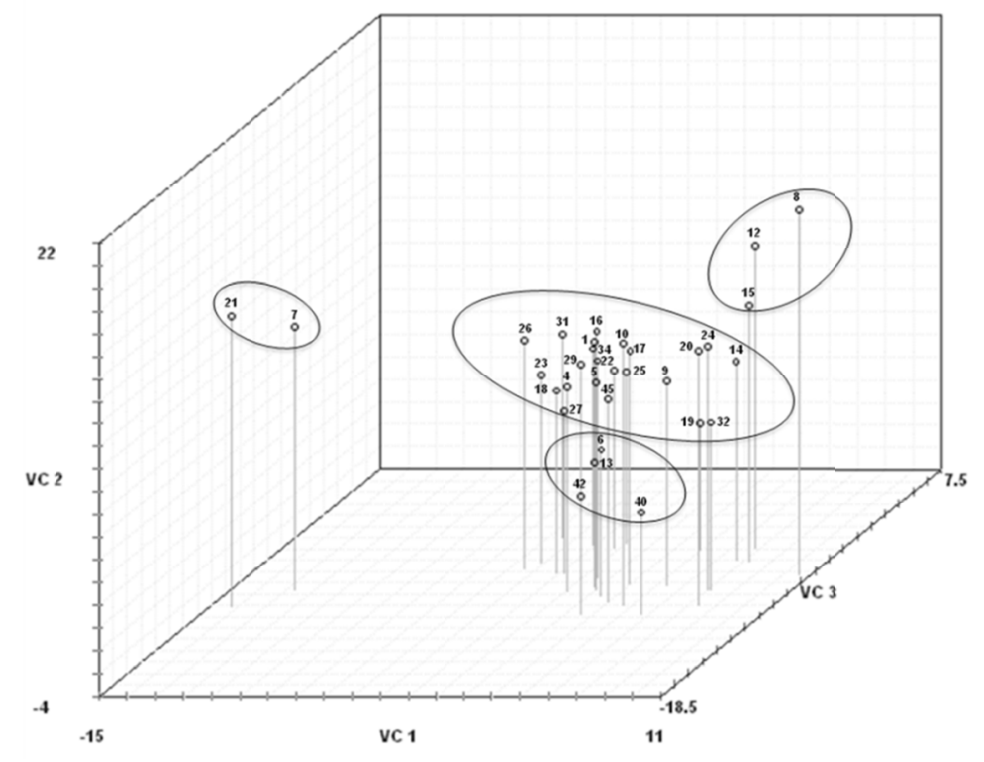

Figure 3. Dispersion graph of the 32 gerbera genotypes using the first three variables

The genetic variability of gerbera found in the present study was also observed by Cardoso et al. (2007) in a study investigating divergence in seven accessions using qualitative and quantitative descriptors; some of these were also incorporated in the present study.

\subsection{Clustering of Qualitative Traits}

To complement the quantitative trait variability analysis, dissimilarity analysis was performed using qualitative descriptors. Such descriptors are extremely important in the identification of accessions with the greatest economic potential and in the design of crosses to produce gerbera cultivars (Neitzke et al., 2010).

Analysis of the qualitative traits allowed for the creation of a dendrogram using the UPGMA algorithm (Figure 4), which revealed five groups based on the average dissimilarity among the investigated accessions $(\mathrm{AD}=0.28)$. 


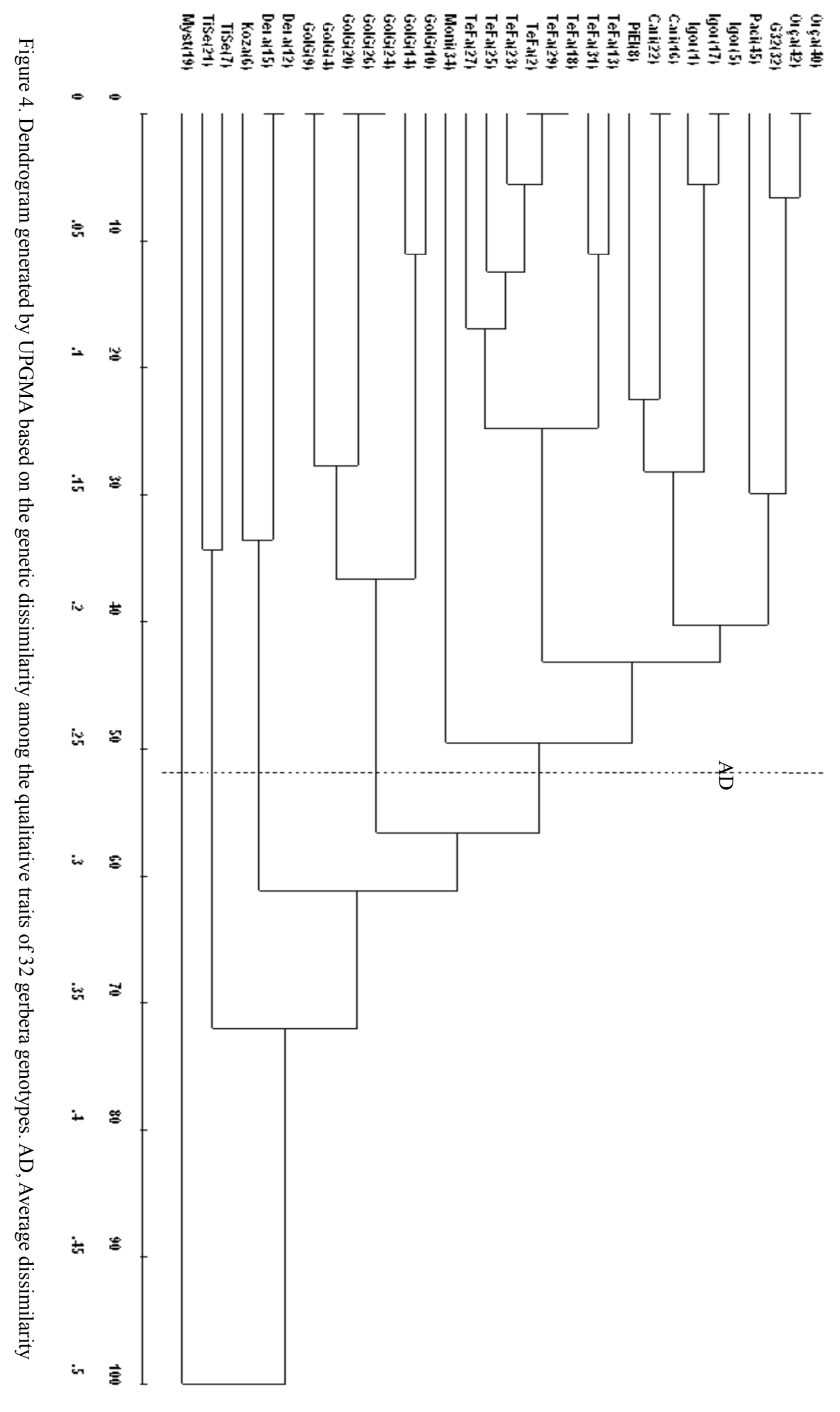


The first group clustered the largest number of accessions, including Orça, G32, Pacific, Igor, Cariba, Pink Elegance, Terra Fame, and Monique. With the exception of Monique, these accessions were monomorphic for the following traits: hairs on the upper surface of leaves (present), depth of incisions at the central third of the leaf blade (shallow), and level of the apex of the outer ray florets relative to the involucre apex (same level). The second group included all of the Golden G. accessions, which were monomorphic for almost all the traits, except for depth of the incisions at the central third of the leaf blade and hairs on the upper surface of leaves. The third group consisted of the Deranagem and Kozak accessions, which were monomorphic for all traits except for dark disk color, main color of the stigma, main color of the anthers, and color of flowers. The fourth group was composed of the wild type accessions, which are not commercially available and were monomorphic for the following traits: green color of leaves, level of the apex of the outer ray florets relative to the involucre apex, and color of flowers. A Mystique accession was isolated in group five and was the only accession whose outer ray florets exhibited two colors.

The correlation coefficient obtained $(\mathrm{r}=0.81)$ was very close to that obtained with the quantitative data $(\mathrm{r}=$ 0.84 ), indicating a good fit and agreement between the clustering analysis and dissimilarity matrix.

The mutually closest accessions with distances of 0.0 were as follows: 2 (Terra Fame) and 12 (Deranagem), 2 and 29 (both Terra Fame), 4 and 9 (both Golden G.), 5 and 17 (both Igor), 12 and 15 (both Deranagem), 16 and 22 (both Cariba), 18 and 29 (both Terra Fame), 20 and 24 (both Golden G.), 20 and 26 (both Golden G.), and 24 and 26 (both Golden G.). The most distant accession was Mystique, with a distance of 0.5. The latter differed from the other accessions insofar as it did not exhibit hairs on the upper surface of leaves.

The results obtained highlight the importance of analyzing both quantitative and qualitative traits insofar as it helps ensure that inferences about inter-accession variability are more reliable.

The importance of studies on genetic divergence for plant improvement reflects the fact that the superiority of hybrids is proportional to the genetic distance between the corresponding progenitors. Therefore, in species where this relationship is observed, breeders have access to a quick and simple criterion for selecting parents for use in hybridization programs, as suggested by Moreira et al. (1994). Unfortunately, few studies on genetic divergence have been conducted with gerbera, as most of the improved genotypes are traditionally developed by private companies (Sparjaaij, 1976). The type of analysis performed in the present study represents a practical and quick approach that may improve decision-making in the design of crosses between highly divergent genotypes, as greater heterotic effect is expected between the most genetically contrasting populations (Falconer \& Mackay, 1996).

As with the present study, countless other studies in different species have shown that analysis of genetic divergence by means of multivariate procedures, such as the Mahalanobis generalized distance and graphical dispersion of mutually concordant canonical variables, is efficient for the discrimination of genotypes. In a study assessing genetic diversity among pepper accessions (Capsicum spp.), Sudré et al. (2006) confirmed the efficiency of multivariate analysis in the characterization of genetic variability among the accessions. Bertini et al. (2010) studied genetic divergence among coriander genotypes (Coriandrum sativum L.) and successfully used multi-categorical variables in the discrimination of genotypes. The applicability of that analysis model was corroborated by Ferrão et al. (2011) in the quantification of genetic divergence among pepper accessions and by Amorin et al. (2007) in their study on the genetic divergence of sunflower accessions. These examples provide evidence for the efficiency of multivariate analysis in the genetic discrimination of individuals and clustering; thus, homogeneity can be exhibited within groups, and heterogeneity can be exhibited between groups. However, the assessment of morphological and phenological traits is time-consuming and may be influenced by the environment. For this reason, an alternative strategy for the study of genetic variability is based on the use of molecular markers. Although studies utilizing molecular markers to assess variability in gerbera are scarce, two examples are those by Da Mata et al. (2009) and Rezende et al. (2009), which utilized random amplified polymorphic (RAPD) markers. In addition, Benemann et al. (2012) identified 17 polymorphic simple sequence repeat (SSR) markers from gerbera expressed sequence tag (EST) databases, allowing for correlations to be made with the morphological traits assessed in their study. Some studies conducted in several species, including plum tree (Shimada et al., 1999), almond tree (Kadkhodaei et al., 2011), chestnut (Serdar et al., 2011), and olive tree (Zaher et al., 2011), have been able to correlate molecular data with morphological and agronomic traits.

Based on the results obtained, it is possible to conclude the following: that there was wide genetic dissimilarity among the 32 gerbera accessions for the quantitative and qualitative traits assessed; that the multivariate techniques employed exhibited partial agreement for the demonstration of genetic variability; that the traits that contributed most to variability were total width of trans florets and number of leaves; and that the genetic 
variability found among the 32 gerbera accessions may be used to perform controlled crosses in genetic improvement programs to develop new cultivars.

\section{Acknowledgements}

The authors wish to acknowledge the Brazilian Federal Agency for Support and Evaluation of Graduate Education (Coordenação de Aperfeiçoamento de Pessoal de Nível Superior-CAPES) for the grant awarded to the first author. The authors also wish to thank the PróClone company, from São Paulo, Brazil, which made available the gerbera accessions from their germplasm bank (PIPE-FAPESP no. 04/02908-0).

\section{References}

Albuquerque, A. N., Barelli, M. A. A., Neves, L. G., Arantes, V. R., \& Silva, K. L. M. (2011). Evaluation of common bean accesses with multi-category variables. Acta Scientiarum Agronomy, 33(4), 627-632. http://dx.doi.org/ 10.4025/actasciagron.v33i4.6944

Amorin, E. P., Ramos, N. P., Ungaro, M. R. G., \& KIihl, T. A. M. (2007). Genetic divergence in sunflower genotypes. Ciência Agrotécnica, 31(6), 1637-1644. http://dx.doi.org/10.1590/S1413-70542007000600006

Beale, E. M. L., Kendal, M. G., \& Mann, D. W. (1967). The discarding of the variables in multivariate analysis. Biometrika, 54(3-4), 357-366. http://dx.doi.org/10.1093/biomet/54.3-4.357

Benemann, D. P., Machado, L. N., Arge, L. W. P., Bianchi, V. J., Oliveira, A. C., Maia, L. C., \& Peters, J. A. (2012). Identification, characterization and validation of SSR markers from the gerbera EST database. Plant Omics Journal, 5(2), 159-166.

Bertini, C. H. M., Pinheiro, E. A. R., Nóbrega, G. N., \& Duarte, J. M. L. (2010). Agronomic performance and genetic divergence of coriander genotypes. Revista Ciência Agronômica, 41, 409-416. http://dx.doi.org/10.1590/S1806-66902010000300013

Borém, A., \& Miranda, G. V. (2005). Melhoramento de Plantas (4th ed.). Viçosa, UFV.

Cardoso, R. D. L., Scheffer-Basso, S. M., \& Grando, M. F. (2007). Genetic divergence in gerbera based on morphological markers. Revista Brasileira de Biociências, 5, 462-464.

Castineiras, L. (1999). Analysis of common bean (Phaseolus vulgaris) descriptors by means of multivariate methods. Ciência de la Agricultura, 39, 54-59.

Cruz, C. D., \& Carneiro, P. C. S. (2006). Biometric models applied to genetic improvement. Viçosa-MG.

Cruz, C. D., Regazzi, A. J., \& Carneiro, P. C. S. (2004). Biometric models applied to genetic improvement. Viçosa-MG.

Da Mata, T. L., Segeren, M. I., Fonseca, A. S., \& Colombo, C. A. (2009). Genetic divergence among gerbera accessions evaluated by RAPD. Scientia Horticulturae, 121, 92-96.

Falconer, D. S., \& Mackay, T. F. C. (1996). Introduction to quantitative genetics (4th ed.). Edinburgh: Longman Group Limited.

Ferrão, L. F. V., Cecon, P. R., Finger, F. L., Silva, F. F., \& Puiatti, M., (2011). Genetic divergence among sub-samples of pepper based on morpho-agronomic characters. Horticultura Brasileira, 29(3), 354-358. http://dx.doi.org/10.1590/S0102-05362011000300016

Filliettaz, A. (2007). Genetic improvement of ornamental plants, 69(2). São Paulo.

Hair, J. R., Joseph, F., Babin, B., Money, A. H., \& Samouel, P. (2005). Fundamentals of management research methods. Porto Alegre: Bookman.

Hermans, C., Hammond, J. P., White, P. J., \& Verbruggen, N. (2006). How do plants respond to nutrient shortage by biomass allocation? Trends in Plant Science, 11, 610-617.

Infoagro. (2012). The gerber daisy growing. Retrieved May 18, 2012, from www.infoagro.com

Junqueira, A. H., \& Peetz, M. S. (2011). (January to May): Net export of Brazilian floriculture. Bulletin of Economic Analysis Market Flowers and Ornamental Plants in Brazil June 2011. Hórtica Consultoria e Treinamento. $\quad$ Retrieved May $4, \quad 2010$, from http://www.hortica.com.br/artigos/2011_janeiro_a_maio_Balanco_do_Comercio_Exterior_da_Floricultura_ Brasileira.pdf 
Kadkhodaei. S., Shahnazari, M., NekoueI, M. K., Ghasemi, M., Etminani, I. A., \& Ariff, A. B. A. (2011). A comparative study of morphological and molecular diversity analysis among cultivated almonds (Prunus dulcis). Australian Journal of Crop Science, 5(1), 82-91.

Mardia, R. F., Kent, J. T., \& Bibby, J. M. (1979). Multivariate analysis. [s.e.]. Academic Press.

Ministry of agriculture, livestock and food supply (2012). Instructions for performing distinguishability, homogeneity and stability assays in gerbera cultivars. Retrieved January 20, 2012, from www.agricultura.gov.br

Morais, H., Marur, C. J., Caramori, P. H., Koguishi, M. S., Gomes, J. C., \& Ribeiro, A. M. A. (2008). Floral bud development, flowering, photosynthesis and yield of coffee plants under shade conditions. Pesquisa Agropecuária Brasileira, 43(4), 465-472. http://dx.doi.org/10.1590/S0100-204X2008000400004

Moreira, J. A. N., Santos, J. W., \& Oliveira, S. R. M. (1994). Approaches and methods for germplasm assessment. Embrapa: Brasília.

Neitzke, R. S., Barbieri, R. L., Rodrigues, W. F., Corrêa, I. V., \& Carvalho, F. I. F. (2010). Genetic dissimilarity among pepper accessions with ornamental potential. Horticultura Brasileira, 28(1), 47-53. http://dx.doi.org/10.1590/S0102-05362010000100009.

Rezende, R. K. S., Paivaii, L. V., Paiva, R., Junior, A. C., Torga, P. F., \& Masetto, T. E. (2009). Genetic divergence among cultivars of gerbera using RAPD markers. Ciência Rural, 39(8), 2435-2440. http://dx.doi.org/10.1590/S0103-84782009005000176

Rocha, M. G. B., Pires, I. E., Rocha, R. B., Xavier, A., \& Cruz, C. D. (2006). Genetic assessment of half-sib progenies of Eucalyptus grandis by means of REML/BLUP and ANOVA. Scientia Florestalis, 71, 99-107.

Rohlf, F. J. (1970). Adaptive hierarchical clustering schemes. Systematic Zool., 19, 58-82.

Serdar, U., Demirsoy, H., \& Demirsoy, L. (2011). A morphological and phenological comparison of chestnut (Castanea) cultivars 'Serdar' and 'Marigoule'. Australian Journal of Crop Science, 5(11), 1311-1317.

Shimada, T., Hayam A, H., Haji, T., Yamaguchi, M., \& Yoshida, M. (1999). Genetic diversity of plums characterized by random amplified polymorphic DNA (RAPD) analysis. Euphytica, 109(3), 143-147.

Singh, D. (1981). The relative importance of characters affecting genetic divergence. The Indian Journal of Genetic and Plant Breeding, 41(2), 237-245.

Sneath, P. H. A., \& Sokal, R. R. (1973). Numerical Taxonomy. Freeman, San Francisco.

Souza, J. C., Menezes, A. C. P., Silva, A. F., Paz, C. D., \& SÁ, P. G. (2005). Artificial hybridization and germination of gerbera (Gerbera jamesonii) seeds in the semi-arid biome. In Brazilian Congress of Olericulture, 45, Brazilian Congress of floriculture and ornamental plants, 15, Braz. Cong. of tissue culture, 2. Abstracts. Fortaleza: SBH (CD-ROM).

Sparnaaij, L. D. (1976). Activities in floriculture plant breeding and genetics in the Netherlands. Acta Horticulturae, 63, 27-36.

Sudré, C. P., Cruz, C. D., Rodrigues, R., Riva, E. M., Amaral, J. A. T., Silva, D. J. H., \& Pereira, T. N. S. (2006). Multicategoric variables for determining the genetic divergence among sweet and chilli peppers. Horticultura Brasileira, 24(1), 88-93. http://dx.doi.org/10.1590/S0102-05362006000100018

Zaher, H., Boulouha, B., Baaziz, M., Sikaou, L., Gaboun, F., \& Udupa, S. M. (2011). Morphological and genetic diversity in olive (Olea europaea subsp. europaea L.) clones and varieties. Plant Omics Journal, 4(7), 370-376. 